\title{
Analysis and implications of challenges in achieving the targets of EU RES-E directive
}

\author{
A. Arasto ${ }^{a}$ \\ L. Kujanpää ${ }^{a}$ \\ T. Mäkinen ${ }^{a}$ \\ R.W.R. Zwart ${ }^{\text {b }}$ \\ J.H.A. Kiel ${ }^{b}$ \\ J. Vehlow ${ }^{\mathrm{c}}$ \\ ${ }^{a}$ VTT Technical Research Centre of Finland, P.O. Box 1000, FI-02044 VTT, Finland \\ ${ }^{b}$ ECN Energy Research Centre of The Netherlands, P.O. Box 1, 1755 ZG Petten, The Netherlands \\ ${ }^{c}$ Karlsruhe Institute of Technology, P.O. Box 3640, 76021 Karlsruhe, Germany
}

Published in Biomass and Bioenergy 38 (2012) 109-116 


\title{
Analysis and implications of challenges in achieving the targets of EU RES-E directive
}

\author{
A. Arasto ${ }^{a, *}$, L. Kujanpää ${ }^{a}$, T. Mäkinen ${ }^{a}$, R.W.R. Zwart $^{b}$, J.H.A. Kiel ${ }^{b}$, J. Vehlow ${ }^{c}$ \\ ${ }^{a}$ VTT Technical Research Centre of Finland, P.O. Box 1000, FI-02044 VTT, Finland \\ ${ }^{\mathrm{b}}$ ECN Energy Research Centre of The Netherlands, P.O. Box 1, 1755 ZG Petten, The Netherlands \\ ${ }^{\mathrm{c}}$ Karlsruhe Institute of Technology, P.O. Box 3640, 76021 Karlsruhe, Germany
}

\section{A R T I C L E I N F O}

Article history:

Received 1 September 2010

Received in revised form

7 February 2011

Accepted 10 February 2011

Available online 1 April 2011

Keywords:

Barriers to bioenergy

EU energy policy

Electricity sector

Renewable energy targets

Energy policy instruments

\begin{abstract}
A B S T R A C T
The Member States of the European Union are on the way to fulfill targets for renewable electricity use set in 2001. In this paper, the implementation of directives concerning renewable electricity is assessed on EU level and in three example countries: Finland, Germany and the Netherlands. Conclusions are drawn regarding policy measures and barriers hindering the exploitation of renewable energy, with a special focus on bioenergy and biomass. Furthermore, in the light of the above-mentioned analysis, the role of bioenergy in the national efforts of reaching the targets for renewable energy use in 2020, as set in the directive 2009/28/EC, is discussed.
\end{abstract}

(c) 2011 Elsevier Ltd. All rights reserved.

\section{Introduction}

Since the adoption of the directive 2001/77/EC [1] on the promotion of electricity from renewable energy sources in the internal electricity market - the so-called RES-E directive - in 2001, implementation of its provisions has progressed. A comprehensive EU regulatory framework is in place and Member States have adopted national targets for green electricity consumption and are working towards them. Looking beyond the targets set for year 2010 by the RES-E directive, new targets are already being discussed for the year 2020 in EU member countries, and due to be published in the national renewable energy action plans during the summer of 2010, as obliged by the recent directive 2009/28/EC [2] on the promotion of the use of energy from renewable sources. In the light of the current energy policy and ambitious targets for greenhouse gas emissions reductions, an assessment of the barriers to the growth of renewable energy sources (RES) use is in order. Moreover, an analysis of the national measures taken to fulfill the RES-E targets are needed, as they pave the way to new energy mixes needed to eventually meet the mandatory national overall shares of renewable energy consumption by the year 2020, as given by the directive 2009/28/EC - known simply today as the RES directive.

In this paper the results of the analysis of the needs and challenges in implementing the RES-E directive, carried out in the Bioenergy NoE Work package IA-9 are presented. Bioenergy Network of Excellence was a project funded by the European Commission's DG Research under the Sixth Framework Program. Bioenergy NoE started in 2004 and ended in 2009. The focus of Work package IA-9 was on analyzing implementation of the RES-E directive in Finland, Netherlands, and Germany with a special focus on electricity production from biomass (bioRES-E). The attention to biomass

\footnotetext{
* Corresponding author. Tel.: +358 20722 111; fax: +358 207227048.

E-mail address: antti.arasto@vtt.fi (A. Arasto).
} 
is due to its applicability across the EU and its available potential compared to virtually fully exploited hydro power potential.

At first, this report gives introduction to RES-E directive implementation in EU27 in general with a special focus on biomass. Then country-specific sections follow, and more detailed analysis on RES-E directive implementation in Finland, the Netherlands and Germany is given. The country reviews include an assessment of the present status of bioRES-E production, a report of trends related to electricity production and especially bioRES-E production during 1990-2007, and an analysis of the competitiveness of bioRES-E during this time. Further, the country-specific reviews list both technical and non-technical barriers met in implementing the RES-E directive. Finally, the main R\&D needs and challenges identified in order to overcome the barriers threatening the attempt to reach the RES-E targets in Finland, the Netherlands and Germany by 2010 are summarized.

\section{Promotion of renewable Energy in the European Union}

The current national targets for RES-E gross inland consumption in 2010 were given in the directive 2001/77/EC. Gross inland consumption is defined in the directive as the quantity of energy necessary to satisfy inland consumption, corresponding to the sum of consumption, distribution losses, transformation losses and statistical differences. The new RES directive sets mandatory national overall targets to the gross final consumption of energy from renewable sources in 2020. The national requirements also include a unified target for renewable energy use in all forms of transportation, equaling a share of $10 \%$ by the same year. The national overall targets have been adjusted in order for the gross final consumption of energy from renewable sources within the Community to reach a $20 \%$ share in 2020 [2].

The Community target of RES-E gross consumption is $22 \%$ of total consumption, as given in the Directive 2001/77/EC. On Community level, the share of gross consumption of electricity from renewable sources has risen from $12.9 \%$ to $15.6 \%$ during the years 2002-2007 (Fig. 1). The growth rate of the

Contribution of electricity from renewables to total electricity consumption on EU27 level

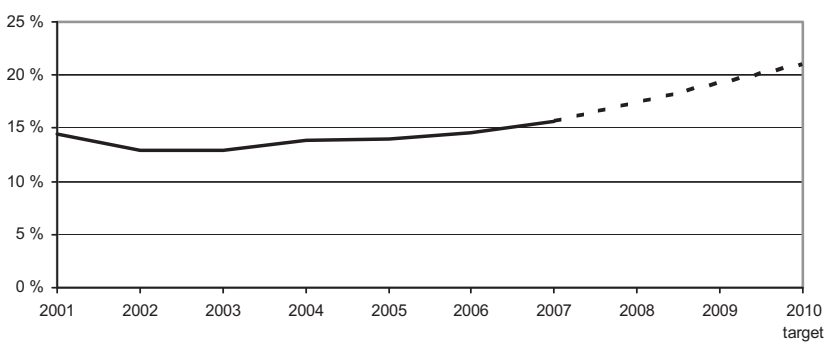

Fig. 1 - The share of gross consumption of electricity from renewable sources during the years 2001-2007. Dash line marks the linearly projected values towards the community target for year 2010 [3].
RES-E share has to increase from $0.5 \%$-point year ${ }^{-1}$ to over 2.1 $\%$-point year ${ }^{-1}$ in order to meet the 2010 target. However, due to the differences between member states in policies, levels of financial support for and key player attitudes towards renewable energy, the increase in the share of RES-E varies significantly on national level.

During 2007, $19.4 \%$ of electricity from renewable sources consumed in EU27 was produced by firing biomass, including bio-fractions of wastes, in CHP and condensing power plants [4].

\subsection{Finland}

For Finland, the indicative target for the share of electricity produced from renewable energy sources (RES-E) is $31.5 \%$ of gross domestic energy consumption by 2010. Depending on the situation with hydro power, this share has varied between $24 \%$ and $30 \%$ in recent years. The output of power plants using biomass-based fuels has increased by over $650 \mathrm{MW}$, hydro power by approximately $220 \mathrm{MW}$, and wind power by approximately $90 \mathrm{MW}$ during the years 1998-2007 [5].

Electricity covers roughly one fourth of the total energy consumption in Finland. In 2007, the total electricity supply was 90.4 TWh, of which $26 \%$ (23.6 TWh) was covered by RES (excluding peat). 26.8 TWh of total electricity supply was produced in CHP plants. Most of the RES-E is hydro power and biomass-based CHP power, which is mainly produced at industrial power plants, especially in the forest industry [5].

In Finland, biomass is defined according to Government Decree No 1357/2003 on Certification of the Origin of Electricity as follows: the biodegradable component in waste, waste products and products derived from agricultural vegetable and animal matter, forestry and related industries, and the biodegradable component of industrial and municipal waste [6]. In addition, peat is categorized as "a slowly renewable biomass fuel" [7]. Use of peat cannot, however, be accounted in the share RES-E. Regarding solid recovered fuel (SRF), it includes $60 \%$ biodegradable fraction according to Finnish legislation. This means that the Finnish biomass definition can be interpreted as a bit wider than the general EU definition.

Next to energy from biomass, hydro power is the second largest source of renewable energy production in Finland. The total hydro power capacity is about $3 \mathrm{GW}$, of which the share of small-scale hydro is $300 \mathrm{MW}$. Hydro power production is very dependent on the water situation each year; annual variations can be as high as $30-50 \%$, which has over the past few years meant annual hydro power production figure as low as 9.6 TWh in 2003 up to 14.9 TWh in 2004. Latest statistics show a hydro power production of 14.2 TWh in 2007. The third source for RES-E production in Finland is wind power, the share of which is for the time being rather marginal compared to hydro power and biomass. Wind power capacity has shown rather weak growth since 2000 , and output has even declined at times due to poor wind conditions. The total final use of wind power was $261 \mathrm{GWh}$ in 2008 [4].

Taxation is one of the main instruments related to climate change and environmental policy in Nordic countries. Finland introduced $\mathrm{CO}_{2}$ taxation in 1990, and the current energy taxation scheme for fuels in heat production has been in force since 1997. The taxes were increased in 2003, partly on the 
basis of $\mathrm{CO}_{2}$ content with the objective of reducing energy consumption and associated $\mathrm{CO}_{2}$ emissions. In addition to the reduction of $\mathrm{CO}_{2}$ emissions, ensuring the competitiveness of domestic energy sources has been the central basis for energy taxation in Finland. Energy taxation affects remarkably the national economy: the state collects annually some 3000 million Euros as a national tax from energy, amounting to around $9 \%$ of all tax income.

Energy taxes are excise duties levied on both traffic and heating fuels and electricity consumption. In addition to the energy tax, a security of supply fee is charged for energy products. The state income from the latter is consolidated and used in maintaining the readiness to supply electricity and other energy products under disrupting and unforeseeable events. The energy tax divides into basic tax, which is fiscal by nature and collected on oil products only, and excise tax collected on oil products and other fossil fuels according to the carbon content and on electricity consumption. The carbon dioxide tax on fuels has been EUR $18.05 \mathrm{t}^{-1}$ of $\mathrm{CO}_{2}$ since 2003 with natural gas having a $50 \%$ reduction in the excise tax [8].

Electricity is taxed at its consumption stage. Consequently, fuels used for power production are tax-free. The tax on electricity is divided into two classes, of which the lower, class II, tax is paid by industry and professional greenhouse cultivation, whilst other consumers pay the higher class I tax.

Regarding RES-E subsidies used in Finland, tax subsidies are paid for power production and energy intensive industry receives tax rebates. Wind power, less than $1 \mathrm{MW}$ hydro power, electricity production from wood and wood-based fuels, recycled fuels and biogas are included in the electricity production support system. In addition to energy taxation, investment subsidies are granted for energy investments, development projects and energy conservation. Investment subsidies are considered on a case-by-case basis, and the maximum percentage for the assistance granted is $40 \%$ of the eligible investment costs.

\subsection{The Netherlands}

The status of RES-E production in the Netherlands during period 1997-2007 has been increasing quite steadily. Over these years the share of RES-E in the national consumption of electricity has increased from 3.5\% in 1997 to $7.6 \%$ in 2007, peaking at $7.9 \%$ during 2006 [3]. The Dutch target for attaining RES-E generation as formulated in EU Directive 2001/77/EC is $9 \%$ in 2010 [1]. Of the total net electricity generated in the Netherlands during year 2008, bioRES-E share was 6.2\% [4].

In order to stimulate RES-E and overcome both financial and non-financial barriers, the Dutch Government deploys a wide range of instruments. These can be divided into financial and non-financial measures. The major financial measure has been the subsidy on environmental quality of electricity production (MEP), currently discontinued for new installations. This was done based on the following: the Dutch government decided that no MEP subsidies shall be provided for new projects, as the RES-E directive target of $9 \%$ by 2010 seems to be achieved. The subsidies of MEP however, are still valid for the companies that were included in the scheme.
Under the MEP scheme [9], Dutch producers of RES-E feeding into the public grid receive a fixed fee per kWh for a guaranteed period of ten years. The amount of subsidy covers the unprofitable component and therefore differs for each renewable energy option, with the amount of subsidy for offshore wind energy taken as the maximum. The MEP scheme is linked with a system of green certificates. The subsidy is financed by all electricity consumers who pay a levy specifically for this scheme but are compensated for this through income tax. The MEP scheme still stimulates the supply of renewable energy.

In light of experience gained with the MEP scheme, the legislation governing the scheme is adapted on a number of points each year. However, the principal characteristics of the scheme (covering the unprofitable component and providing a guaranteed fixed amount of subsidy throughout the MEP period) remain unchanged. The level of the MEP subsidies required bridging the difference between cost and market prices for each RES-E source and technology is based on periodic assessments of the financial viability of the different RES-E production technologies by ECN and KEMA. The MEP scheme, therefore, provides a representation of the competitiveness of RES-E and/or bioRES-E by fuel, type, technology and capacity.

As the level of the MEP subsidies were based on periodic assessments, the levels changed significantly over time for different technologies, capacities, locations and fuels. The point in time the official application for MEP subsidies was submitted is of importance as well, as the initial level will be valid with duration of maximum 10 years.

In addition to the MEP scheme the Dutch Government has deployed a wide range of other financial measures to stimulate bioelectricity, e.g. the energy investment deduction scheme (EIA), the tax relief schemes for investments in environmental friendly machinery (MIA and Vamil) and the energy research strategy (EOS) program. The discontinued MEP scheme itself was replaced by SDE scheme in 2007 [10].

\subsection{Germany}

In Germany, the target for 2010 is that RES share in gross electricity consumption should have risen to at least $12.5 \%$. The contribution of electricity from renewable sources of energy reached the level of $15.1 \%$ in 2008 (14.2\% in 2007). In addition to the RES-E directive target, the Federal Government's goal is to increase RES share in overall energy supply to at least $4.2 \%$ by 2010 . In 2008 , the share energy from renewable sources in total final energy consumption was $9.5 \%$ after $9.8 \%$ in 2007, which means that the 2010 goal has already been achieved and by far exceeded [11].

Regarding bioRES-E market development, RES-E generation with solid biofuels dominates with $44 \%$ the biogenous electricity market (in year 2008). These are mainly wood power plants up to $20 \mathrm{MW}$ installed electric capacity $[11,12]$.

The requirements of the RES-E directive are integrated in German law mainly by the Act on Granting Priority to Renewable Energy Sources (Renewable Energy Sources Act/EEG) from the year 2000 and its first amendment from 2004 [13]. The Renewable Energy Sources Act obliges electricity grid operators to give priority to the purchase of electricity from solar energy, hydro power, wind power, geothermal power and biomass, and 
to pay a specified price for it. The level of compensation is based on the production costs. As investors know for certain that they can sell their electricity at a fixed rate for 20 years, the banks will give the credits needed. This has resulted in the desired boom in the construction of new installations [12].

The amended EEG encourages new biomass power plants mainly with small and middle sized capacity (up to $5 \mathrm{MW}$ ). With the CHP bonus there is an approach to higher the efficiency of the facilities. In addition, there are incentives to operate CHP facilities, which are charged with forest wood [14]. In addition to EEG, also emission trading directive has its effect on the competitiveness of biomass-based fuels in power production.

\section{Results}

\subsection{Implications of RES-E directive and national support schemes to the profitability of RES-E}

The different national policies have led to a situation in which the value of bioRES-E varies country-by-country (Fig. 2). Moreover, in the countries with a low electricity price, there is not much interest in investing since the profit expectation is low. Internal rate of return (IRR) is used here to compare the relative profitabilities of investments of different sizes on various production plants. The production technologies are compared, as the level of support varies depending on the chosen technology. The IRRs for bioRES-E production by four different technologies in Finland, Germany, and The Netherlands are shown in Fig. 3. The comparison shows significant differences in IRRs between the three countries and BioRES-E production technologies. The profits in relation to the investments clearly are highest in Germany among the three countries. Diverse feed-in tariffs also distort the markets and can be considered as a major driver of international biomass trade.

\subsection{Barriers to achieving RES-E targets in Finland}

One of the main barriers hindering further use of biomass in power production is low electricity prices. The low price level derives from reliance on nuclear energy, hydro power, and efficient use of fossil energy sources in CHP plants in the production of the electricity base load. Around one-third of the electricity production is based on emission-free nuclear power. The available major hydro power resources permitted by current legislation have been built. Finland uses a lot of combined heat and power production both in industry and district heating. The combined heat and power production is competitively priced and emissions are low per produced energy unit. In European comparison, the cost of electricity in Finland is low for the end user [17]. In addition to low electricity prices, dependence on the output of forest industry is another major factor limiting the sought increase in bioRES-E production, as around $80 \%$ of the energy derived from wood in Finland is generated and used in the forest industry.

The target set by the RES-E directive for Finland is challenging in Finnish conditions, since production from the leading domestic RES, hydro power, can hardly be increased. In fact, the annual fluctuation in electricity produced by hydro

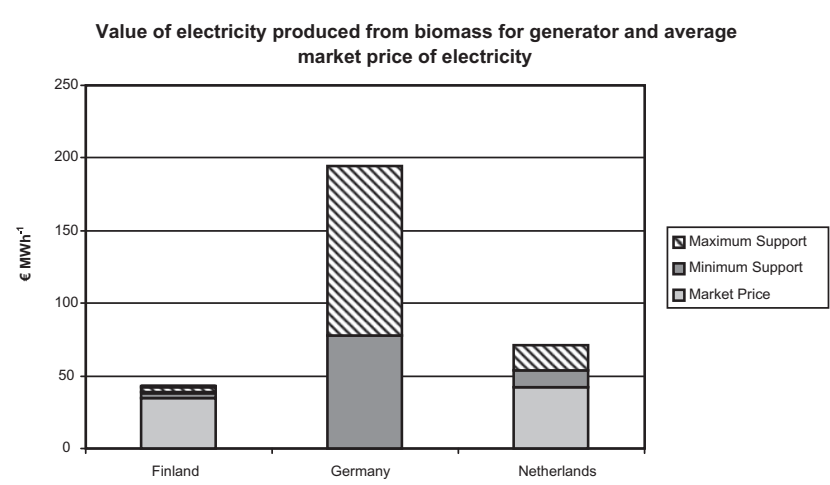

Fig. 2 - Value of the electricity produced from biomass for the generator in the example countries, $€ / \mathrm{MWh}^{1}$

power is one of the biggest uncertainty factors on the Nordic electricity market. During years of low precipitation, reaching the RES-E target of $31.5 \%$ becomes impossible in Finland. No significant increase in either hydro or wind power production is forecast before year 2010 [18].

Many power plants using wood fuels use also peat due to its fixed price, quality and availability. Often the price of peat acts as a reference price for wood fuels being the highest price plants are willing to pay for wood fuels. Power plants' solvency margin for wood fuels is comprised of following factors: the price, taxation and feed-in tariff of peat, support received by wood fuels, as well as the price of emission allowances.

Besides promotion incentives, emission trading has contributed greatly to the competitiveness of biomass-based fuels in power production. However, though electricity prices have increased, prices are still "too low" for new investments: when electricity price is low, there is not much interest in investing new technology with high power-to-heat ratios and high specific investment costs since the profit expectation is low. For example, increasing the use of forest residues as a fuel in CHP plants of small heat demand is potential but unprofitable means to increase bioRES-E production [19].

The most remarkable means to increase bioRES-E production are assessed to be the following according to reference [20]: Small-scale backpressure power plants, largescale backpressure power plants, energy use of recovered fuels, agro biomass fuels and co-firing of biomass with coal.

\footnotetext{
${ }^{1}$ In the example countries the different combinations of feed-in tariffs, tax refunds, green certificates and quota obligations are used. The amount of the support depends on e.g. a type of biomass fuel used and a size of installation. The minimum support is the minimum amount of support a bioelectricity producer receives in a certain country and respectively the maximum support is the maximum amount of support a bioelectricity producer can receive. Certificate prices are estimated from average stock electricity prices. Minimum price of certificate depends on the year and approaches zero in time. The theoretical maximum price for certificates exists as the buyout price. Market prices are estimated from average regional electricity stock market prices as well. A German producer of BioRESE receives a fixed feed-in tariff as the income, as the actual market price is lower $[8,10,13,15,16]$.
} 
IRR for typical biomass fired powerplants in different countries

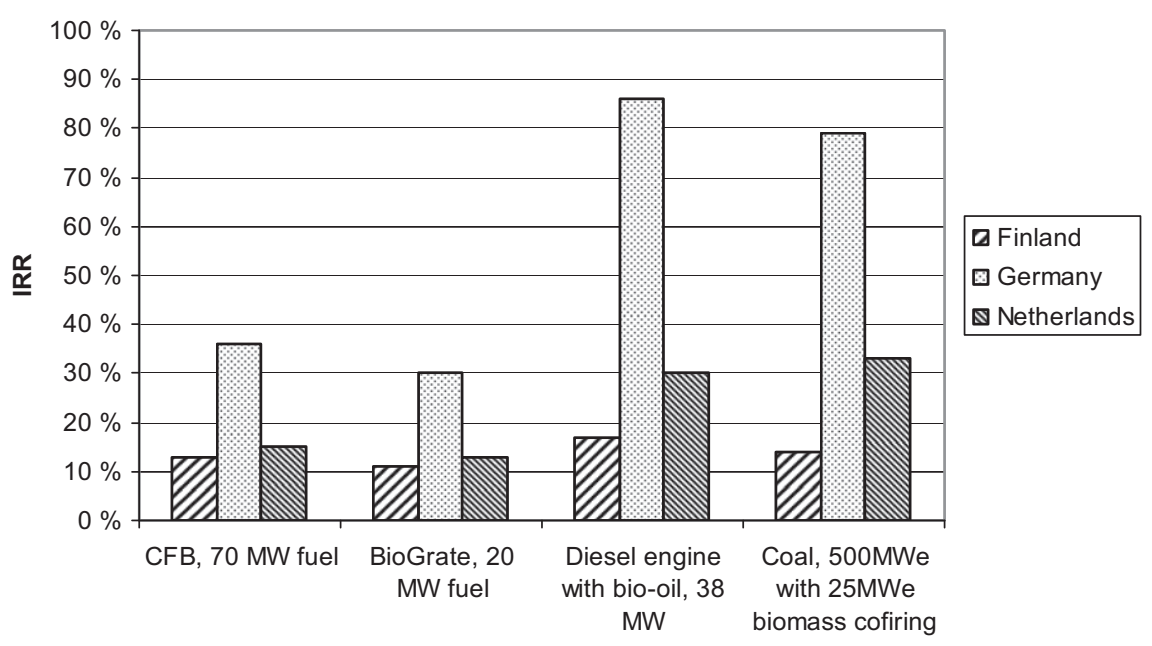

Fig. 3 - Internal rates of return (IRR) of some biomass-fired power plant types in Finland, Germany, and the Netherlands. Values of electricity production are estimated based on average stock market prices and national fiscal incentives $[8,10,13,15,16]$.

\subsection{Barriers to achieving RES-E targets in the Netherlands}

Over the last years the electricity production from renewable energy sources in the Netherlands has increased significantly from $2.5 \%$ in 2000 and $7.6 \%$ in 2007 . Although much small-scale bioenergy projects were initiated, the principal growth over the last years was in the wind energy and the additional use of biomass for co-firing. These are by far the most important sustainable energy options in the Netherlands. Given current trends, it is expected that the $9 \%$ target can be properly achieved in 2010.

For reaching the objectives, however, the large-scale installations are again especially important. The number of ongoing projects is largely sufficient, although there are still many that do not yet have obtained licenses. These yet still failing licenses, as well as the fact that the MEP subsidies are no longer granted to new installations, along with the current uncertainty if the new subsidy instruments will compensate the application of biomass sufficiently, are considered to be the main risks compromising the achievement of the RES-E target set for 2010. According to a recent inventory the import of biomass flows is no longer profitable considering the low levels of MEP subsidy. It therefore must be concluded that the implementation of bioenergy is still very vulnerable to changes in the market situation.

At the end of 2003 the Dutch Biomass Action Plan was presented to the Lower House of Parliament. This plan listed a number of barriers for all stakeholders hampering the use of biomass in the Netherlands. Besides the financial-economic problems, these included: licensing problems, communication, biomass supply and availability, problems concerning knowledge and technology and problems concerning level playing field within the EU.

\subsection{Barriers to achieving RES-E targets in Germany}

In addition to reducing energy consumption and increasing energy efficiency, expansion of RES is a central element in the
German Government's energy policy. The target for 2010 is that RES share in gross electricity consumption should have risen to at least $12.5 \%$. Although the RES-E targets are currently met, the use of biomass in Germany is still limited or shows room for improvement. Barriers hindering the further use of biomass in power production are economics, undeveloped use of residues, and complex legislation [12]. Only a small part of the technical power generation potential is exploited [21].

In 2005, the share of energy from renewable sources in primary energy consumption was $4.6 \%$, which means that the Federal Government's 2010 target has already been achieved. That is primarily due to the fact that renewable energies are promoted in the electricity sector under the Renewable Energy Sources Act (i.e. EEG) and in the heating sector by a program of market incentives. In addition to EEG, also emission trading directive has its effect on the competitiveness of biomassbased fuels in power production.

In regards to further RES-E increase, firstly, EEG continuity beyond 2007 with long-term guaranteed, fixed but differentiated compensation fees and the compulsory acceptance of the system by grid operators are vital for further investments in the electricity sector. Secondly, the feed-in tariffs should be evaluated and adjusted to market needs regularly to mobilize idle biomass potentials. And thirdly, the CHP bonus should be adjusted, e.g. higher bonus for forest residues [14].

\subsection{Summary of found barriers}

As a summary, the identified barriers are presented in Table 1. Although improving the economic position of biomass would seem to remove most of the identified barriers, challenges remain in choosing the optimal subsidy levels while ensuring stable and low-risks investing environment for energy companies. Nevertheless, the administrative and grid access barriers to the growth of renewable energy sources use need to be removed at European, national and local levels. 
Table 1 - Summary of barrier analysis on the promotion of electricity from renewable sources.

\begin{tabular}{|c|c|c|c|}
\hline $\begin{array}{l}\text { Barriers } \\
\text { concerning: }\end{array}$ & Finland & Netherlands & Germany \\
\hline $\begin{array}{l}\text { Economics, } \\
\text { taxation } \\
\text { and subsidy } \\
\text { schemes }\end{array}$ & Low energy prices & $\begin{array}{l}\text { Uncertain } \\
\text { effectiveness of } \\
\text { subsidy } \\
\text { schemes. }\end{array}$ & \\
\hline $\begin{array}{l}\text { Biomass } \\
\text { resources }\end{array}$ & $\begin{array}{l}\text { Biomass } \\
\text { consumption } \\
\text { dominated by } \\
\text { forest industry. }\end{array}$ & $\begin{array}{l}\text { Biomass } \\
\text { availability } \\
\text { dependent on } \\
\text { trade. }\end{array}$ & \\
\hline $\begin{array}{c}\text { Technologies } \\
\text { in biomass } \\
\text { utilization }\end{array}$ & $\begin{array}{l}\text { Undeveloped use } \\
\text { of residues. }\end{array}$ & & $\begin{array}{l}\text { Undeveloped } \\
\text { use of } \\
\text { residues. }\end{array}$ \\
\hline Legal issues & & $\begin{array}{l}\text { Complex } \\
\text { legislation \& } \\
\text { contingencies in } \\
\text { licensing }\end{array}$ & $\begin{array}{l}\text { Complex } \\
\text { legislation }\end{array}$ \\
\hline
\end{tabular}

\subsection{Opportunities in expansion of RES-E generation}

As the EU is already exploiting almost all its hydro power potential, future growth of RES-E production will have to rely on wind, bioenergy and solar power. As a consequence, national policies deriving from the RES-E directive are likely to increase demand for bioenergy. Some EU27 countries have special feed-in tariffs for electricity produced from biomass (bioRES-E). In some countries, feed-in tariffs are augmented by support for investments in bioenergy installations in the form of grants or loans on favorable terms, for example.

The bioRES-E potential which can be achieved using the current technology and new technology by 2010 was estimated for the example countries. Bioelectricity production potential in 2010 using current technologies is estimated based on the current bioRES-E production and increasing the production by conventional co-firing and small-scale production technologies. The estimated potential using advanced technologies is

RES-E gross consumption, targets and biomass technology

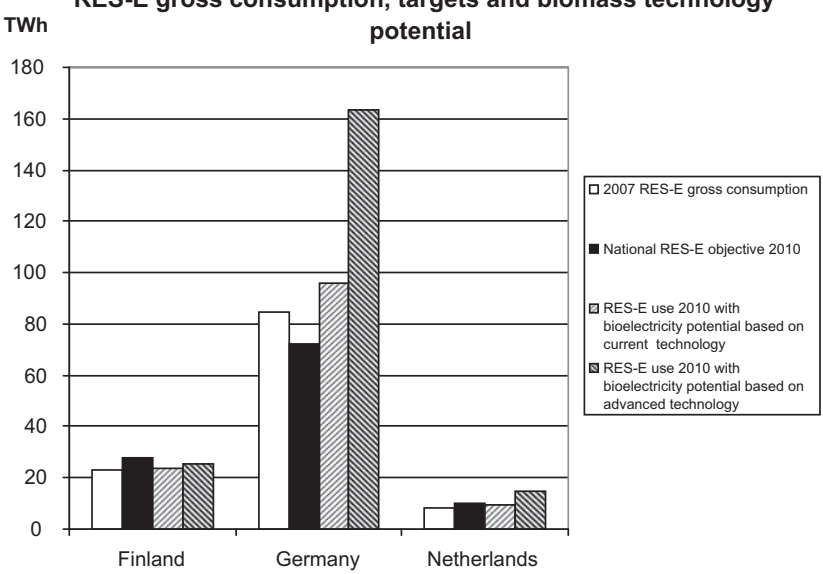

Fig. 4 - Current production of electricity based on renewable energy sources, national policy targets for RES-E and RES-E potential in 2010 in Finland, Germany and The Netherlands [1,4]. based on the current RES-E production and increasing the production using advanced technologies for biomass co-firing and small-scale bioelectricity production, e.g. co-firing based on biomass gasification and small-scale bioelectricity production concepts with higher power-to-heat ratio.

Potential RES-E production using advanced technologies for biomass-based electricity production is higher than the national targets for RES-E use in 2010 in all countries considered, except in Finland (Fig. 4). With conventional technologies, the RES-E targets could be achieved only in Germany. According to this rough analysis, especially Germany has a huge potential for advanced co-firing technologies. However, only technological potentials have been included in these estimations, and assessments of biomass resource potentials or economical evaluations of investments have not been taken account. Current RES-E use is based on Eurostat Statistics [3] and national RES-E objectives are based on indicative targets of Directive 2001/77/EC on the promotion of electricity produced from renewable energy sources.

\section{Conclusions \& discussion}

\subsection{Identifiable $R \& D$ needs}

Several R\&D needs and challenges can be identified in order to overcome the barriers threatening the attempt to reach the RES-E targets by 2010 focusing on the example countries Finland, the Netherlands and Germany.

Especially in Finland, a great potential in increasing the biomass fuels in RES-E productions lies in the promotion of the use of residues. Opportunities exist in increasing the use of forest residues, waste derived fuels like SRF, agricultural residues like straw and annual crops in CHP production in both industrial and municipal sectors. Co-firing of low grade fuels should be demonstrated in large-scale fluidized-bed CHP plants at a high power-to-heat ratio. The ultimate challenge and novelty lies in reaching substantial co-combustion shares, even up to $50 \%$, of residual fuels in large-scale CHP plants without decreasing the plant availability by serious fouling and corrosion problems.

Gasification and co-combustion of product gas on high efficiency CHP plants offers the same possibilities of high power-to-heat ratio as co-firing. Currently an EU funded waste gasification demonstration project (LahtiStreams) is implemented with participation of two former Bioenergy NoE partners (VTT, KIT). In the project, gasification of sourceseparated waste and gas cleaning and co-combustion of the product fuel gas in a coal-fired boiler will be demonstrated in Lahti, Finland.

Co-firing of biomass in existing fossil-fuel fired power plants is an important option for generation of renewable electricity. E.g. in the Netherlands the co-firing of biomass in existing coal-fired boilers is the main technology to achieve the targets of the RES-E directive. Currently co-firing is in the most cases limited to the use of relatively small percentages of biomass in conventional pulverized coal combustion plants. A full exploitation of the prospects of co-firing requires the use of higher percentages of biomass, co-firing in advanced coal 
plants (ultra super critical boilers and IGCC plants) and indirect co-firing in natural gas fired plants. $R D \& D$ is required to implement the prospects of co-firing.

In addition to research and development work systems studies are important for removing the barriers on increasing bioRES-E production, e.g. effects of the emission trade scheme on the competitiveness of biomass-based fuels in power production should be understood. Understanding the value of the whole chain from fuel production to combustion is important, e.g. logistics of fuel procurement is essential for cost-efficient bioRES-E production.

\subsection{Future beyond the RES-E directive}

As the RES-E directive concerned only gross consumption of electricity from renewable sources, a need for assessing the promotion of renewable energy in heat and transportation sector remained after its publication. Directive 2003/30/EC soon followed, setting un-binding targets for road transportation, while RES use in heat sector was still left without promoted [22]. Instead of diversifying the Community's legislation with a third supplemental directive, the RES promotion needs were brought under a single directive, the so-called RES directive. It sets a binding target of $20 \%$ for the share of all renewable energy in overall EU energy consumption by 2020. Moreover, the share will be calculated by comparing the gross final energy consumption of electricity, heat and transport fuels produced from renewable sources to the gross final total energy consumption.

Fulfilling the binding targets of $20 \%$ for the share of renewable energy in overall EU energy consumption by 2020 , as required by the RES directive will require a massive growth in all three renewable energy sectors: electricity, biofuels and heating and cooling. However, it remains unclear how the member countries will decide to do the burden-sharing between these sectors. Using the gross final consumption of energy as the measure of RES use could direct the biomass flows to utilities which are not burdened by low efficiencies of primary energy use. Will the available biomass resources be used by industries, services and households as heat, where efficiency penalties do not count, rather than in biomassbased electricity production, remains to be seen. Each Community member state will have to take these issues into close consideration while agreeing upon the national renewable energy action plans and further considering their national energy policies.

\section{Acknowledgements}

This paper was based on work conducted in the Bioenergy Network of Excellence: Overcoming Barriers to Bioenergy (2004-2009), a project funded by the European Commission's DG Research under the Sixth Framework Program. The authors would like to acknowledge the community of researchers from the eight research institutes from across Europe participating in the Bioenergy NoE during the past years.

\section{REFERENCES}

[1] Directive 2001/77/EC of the European Parliament and of the Council of 27 September 2001 on the promotion of electricity produced from renewable energy sources in the internal electricity market. Off J Eur Union 27.10.2001. L 283/33.

[2] Directive 2009/28/EC of the European Parliament and of the Council of 23 April 2009 on the promotion of the use of energy from renewable sources and amending and subsequently repealing Directives 2001/77/EC and 2003/30/ EC. Off J Eur Union 5.6.2009. L 140/16.

[3] Eurostat, Share of renewable energy - contribution of electricity from renewables to total electricity consumption (\%). Available on-line from: http://epp.eurostat.ec.europa.eu/ portal/page/portal/energy/data/database [accessed 30.10.09].

[4] Eurostat, Energy statistics - Infrastructure - Electricity Annual data. Available on-line from: http://epp.eurostat.ec. europa.eu/portal/page/portal/energy/data/database. [accessed 30.10.09].

[5] Statistics Finland. Production of electricity and heat. Stat Finland Database, http://www.stat.fi/til/salatuo/index_en. html; 2009 [accessed 30.10.09].

[6] Government Decree No 1357/2003 on certification of the origin of electricity, Finland, http://www.finlex.fi/en/laki/ kaannokset/2003/en20031357.pdf; 2003.

[7] Ministry of Industry and Trade. The Finnish national climate strategy, http://www.ktm.fi/index.phtml?c=www\&l=en\&s= 198; 2001 [accessed 30.06.05].

[8] Government decree No 1168/2002, Finland, http://www. finlex.fi/fi/laki/alkup/2002/20021168; 2002 [in Finnish].

[9] European Renewable Energy Council. Renewables energy policy review - The Netherlands, http://www.erec.org/ fileadmin/erec_docs/Projcet_Documents/RES2020/ NETHERLANDS_RES_Policy_Review_09_Final.pdf; 2009 [accessed 24.01.11].

[10] Regulation of the Minister for Economic Affairs of 16 March 2009, no. WJZ/9051027, concerning indication of categories production installations for the stimulation of durable energy production in the year 2009, The Netherlands, 2009.

[11] Bundesministerium für Umwelt, Naturschutz und Reaktorsicherheit. Renewable energy sources in figures national and international development. Germany: Federal Ministry for the Environment, Nature Conservation and Nuclear Safety, http://www erneuerbare-energien.de/files/english/renewable_energy/ downloads/application/pdf/broschuere_ee_zahlen_en.pdf; 2009 [accessed 28.10.09].

[12] Stinshoff V, Pries S. The role of bioenergy in the national legislation and implementing EU directives. EUBIONET II WP3 country report of Germany. EUBIONET II - EIE/04/065/ S07.38628, http://www.eubionet.net/ACFiles/Download.asp? recID $=4120 ; 2006$ [accessed 10.10.06].

[13] Act revising the legislation on renewable energy sources in the electricity sector, Germany, 21 July 2004. Germany, http:// www.bmu.de/files/english/pdf/application/pdf/eeg_en.pdf; 2004.

[14] Siegmud T. German bioenergy association, http://www. germanrenewableenergy.com/Renewables/Redaktion/PDF/ es/es-Hannover-Messe-Energy-2006-Siegmund-Bioenergy, property $=$ pdf,bereich $=$ renewables, sprache $=$ de, $r w b=$ true. pdf\#search=\%22German\%20BioEnergy\%20Association\%22; 2006 [accessed 10.10.06].

[15] Nordpool. Nordpool system price, http://www.nordpool.com [accessed 30.10.09].

[16] APXGroup. APX power NL Day price, http://www.apxgroup. com [accessed 30.10.09]. 
[17] Kara M. Electricity and emission allowance markets from a Finnish viewpoint - Study. VTT Research Notes 2341, http://virtual.vtt.fi/inf/pdf/tiedotteet/2006/T2341.pdf; 2006 [accessed 30.08.06].

[18] Ministry of Employment and the Economy. National climate and energy strategy, 2005, Finland. Outline of the energy and climate policy for the near future - National strategy to implement the Kyoto Protocol. Government Report to Parliament 24 November 2005, http://www.tem.fi/files/16129/ jul27eos_2005_eng.pdf; 2005.

[19] Electrowatt-Ekono Oy. Asiantuntijalausunto vihreiden sertifikaattien sopivuudesta uusiutuvan energian tukemiseen Suomessa, http://www.tem.fi/files/15619/Electrowatt-Ekono_ 28062005_Lausunto_KTM_Ekono.pdf; 2005.
[20] Helynen S, Sipilä K, Flyktman M. Assessing the bioenergyrelated background assumptions and targets in the action plan on renewable energy (Uusiutuvien energialähteiden edistämisohjelman bioenergiaa koskevien taustaoletusten ja tavoitteiden arviointi). 28 p + app. 4 p, http:// julkaisurekisteri.ktm.fi/ktm_jur/ktmjur.nsf/All/ 230E73326353FD0BC2256FF6002DC538/\$file/324642004.pdf; 2005 [in Finnish].

[21] AGEE-Stat. Trends in renewable energies in 2005. Current situation, http://www.erneuerbareenergien.de/inhalt/36948/ 36356/; May 2006 [accessed 10.10.06].

[22] Directive 2003/30/EC of the European Parliament and of the Council of 8 May 2003 on the promotion of the use of biofuels or other renewable fuels for transport. Off J Eur Union 17.5.2003. L 123/42. 